\title{
4 \\ Theorizing Multiculturalism: Modeling the Dynamics of Inclusion and Exclusion in School-Based Multicultural Settings
}

\author{
Lee Gunderson
}

\subsection{Introduction}

A theoretical review of multiculturalism is incredibly complex. I am aware, for instance, of the complexities and arguments associated with multiculturalism (called multiracialism in Singapore) in many Asian countries. Considering the multiple discourses involved in all of the countries in Asia and the vastness of the topic, I will focus on multiculturalism as it relates to teaching and learning in classrooms that, I am aware, are filled with students with varying cultural backgrounds. This chapter will include some views of individuals I have described in previous reports (Gunderson, 2000, 2007). My purpose is to develop a multicultural model that can be argued, contested, discussed, and possibly observed and tested in classrooms and schools in Asia.

Millions of people around the world are enrolled in classes where they learn a language different from the one they speak at home; they are also immersed in a culture different from their first one (Gunderson, Odo, \& D'Silva, 2011). In British Columbia, Canada, for instance, it is not unusual to find classrooms that are filled with students from various cultural backgrounds. Matsumura (2012, personal communication) describes one school in Shiga, Japan, that has a majority of students from Brazil who speak Portuguese but are ethnically Japanese. I have visited many classrooms in Asia with multicultural students. In some cases, students are native-born, but their culture differs from the mainstream culture. In other cases, there are students who are immigrants or come from families that are temporary or work-stay immigrants; they are sometimes called sojourners. But let me first define "culture." 


\subsection{Culture}

About 60 years ago, Kroeber and Kluckhohn (1954) recognized 160 different definitions of culture. Larson and Smalley (1972) proposed that culture represented a map or blueprint which guides the behavior of people in a community and is nurtured in family life. Culture organizes our behavior in groups, makes us sensitive to matters of status, and assists us to know what others expect of us and what will happen if we do not live up to expectations. Culture helps us to know how far we can go as individuals and what our responsibility is to different groups. "Different cultures are the underlying structures which make Round community round and Square community square" (Larson \& Smalley, 1972, p. 39).

Condon (1973) proposed that culture "is a system of integrated patterns, most of which remain below the threshold of consciousness, yet all of which govern human behavior just as surely as the manipulated strings of a puppet control its motions" (p. 4). Vontress (1976) concluded that each of us lives in five cultures that intermingle: the universal, ecological, national, regional, and racio-ethnic. Culture is more than the sum of its parts and each of us is more culturally complex than we realize or can describe. Culture allows human beings to survive by providing them the mental constructs to categorize the world. Murdock (1961) describes seven characteristics of cultural patterns: (1) they originate in the human mind; (2) they facilitate human and environmental interaction; (3) they satisfy basic human needs; (4) they are cumulative and adjust to changes in external and internal conditions; (5) they tend to form a consistent structure; (6) they are learned and shared by all the members of a society; and (7) they are transmitted to new generations. Culture can be viewed at two levels: macro-a broad generalization consisting of shared features across a group-and micro-particular features related to an individual or a very small group of individuals.

A discussion of culture often includes descriptions, discussions, and arguments for and against such issues as race, ethnicity, socioeconomic status, economy, gender, religion, and political philosophy. Culture is defined within the parameters of a particular academic perspective. Sociolinguistic definitions differ from anthropological definitions, which differ from ethnolinguistic definitions, and so on. Culture affects the way an individual perceives the world on both macro- and micro-levels. Culture has a direct relationship with one's beliefs about, attitudes toward, expectations for, and views of teaching and learning, and the importance of learning. 
When individuals move from one culture to another, there are both micro- and macro-level consequences. According to Schumann (1978a), micro-level features may include such phenomena as culture shock, motivation, and ego permeability. Schumann categorized acculturation relative those who wish to assimilate fully into a culture and those who do not. Schumann (1978a,b, 1986) proposed that two factors affect the degree to which a learner acculturates: social and psychological distance. Variables related to social distance include social dominance, integration pattern, enclosure, cohesiveness, size, cultural congruence, attitude, and intended length of residence. Psychological distance is related to language shock, culture shock, motivation, and ego permeability.

Schumann sees culture shock as one of the most difficult experiences that immigrants encounter. He argues that one who is new to a culture begins to go through acculturation and other processes, during which there are "stages" that represent the degree to which one has become part of or adapted to the new culture.

In acculturation, an individual from one culture must adapt to a new culture. In assimilation, on the other hand, an individual's first culture is submerged in the new one and there is often a loss of values, beliefs, and behavior patterns of the original culture. Acculturation is often associated with an individual's success in learning a new language. Indeed, many have suggested that the failure to acculturate is often associated with the failure to learn a second language (Ellis, 1985).

"Normal" acculturation occurs in four stages: euphoria, culture shock, recovery, and acculturation. "Under normal circumstances, people who become acculturated pass through all the stages at varying rates, though they do not progress smoothly from one stage to the next and may regress to previous stages" (Richard-Amato, 1988, p. 6). There is variation in acculturation, both between and within cultural groups.

A number of factors affect the degree to which individuals become acculturated: nation of origin, reasons for immigrating, age on entry, amount of prior schooling, economic status, difficulties related to travel, extent of disruption and trauma related to war, and a family's immigration status (Gunderson, 2007). Schumann's (1978a) model "seeks to explain differences in learners' rate of development and also in their ultimate level of achievement in terms of the extent to which they adapt to the target-language culture" (Ellis, 1994, p. 230). Acculturation, according to Schumann, means "the social and psychological integration 
of the learner with the target language (TL) group" (Schumann, 1986, p. 379). However, a number of researchers carry a negative view of acculturation.

Second-language researchers have suggested that acculturation is negative (see, for instance, Duff \& Uchida, 1997) because it depicts the secondlanguage learner as one who must give up a first culture. Socialization theorists have a more positive view, though. Duff (2010) notes that "students in classrooms are often socialized into and through discourse of (showing) respect (and self-control, decorum) to teachers, to one another, and to the subject matter itself" (p. 173). Children and other novices learn to function communicatively with members of a community by organizing and reorganizing sociocultural information that is conveyed through the form and content of the actions of others (Schieffelin \& Ochs, 1986a,b). Schieffelin \& Ochs (1986b) conclude that as children learn to become competent members of their society, they also learn to become competent speakers of their language. Talmy (2012) states that secondlanguage socialization research "is typically longitudinal, ethnographic in design, and favors analytic frameworks that allow for the examination of microgenesis and ontogenesis in (L1 and L2) linguistic and other social practices, as well as how such practices relate to matters of extrasituational, or macro, cultural and social logical significance" (p. 571). Duff and Talmy (2011) note, "Language socialization also differs from cognitivist SLA in its focus on the local social, political, and cultural contexts in which languages are learned and used, on historical aspects of language and culture learning, on contestation in chains across timescales, and on the cultural content of linguistic structures and practices" (p. 96). It is suggested here that the potential for socialization in classroom discourses is associated with a number of cultural features and variables.

\subsection{Propaedeutic to a multicultural model}

\subsubsection{Teaching and learning}

Teaching and learning, that is, schooling, are not culture-free. I conclude that "North American educators continue to view education within a 'mainstream' viewpoint, one that focuses on European values and beliefs, even though their school populations grow increasingly multicultural" (Gunderson, 2000). It is clear that immigrant students bring with them complex cultural beliefs about teaching and learning that are, in many respects, different from the views of mainstream teachers and students (Gunderson, 2007). 


\subsubsection{Significant cultural variables}

I believe that culture constitutes the ideas, customs, language, arts, and skills that characterize or reflect a group of individuals in a given period, particularly as they relate to the scholastic learning of the group's members. However, culture is not a singular unitary phenomenon. Indeed, human beings live within the contexts of multiple cultures. In a study of secondary students, Gunderson (2000) notes, "Members of the diasporas in this study were lost in the spaces between various identities: the teenager, the immigrant, the first language speaker, the individual from the first culture, the individual socializing into a second language and culture, the individual in neither a dominant first or second culture but one not of either culture" (p. 702). People exist in multiple intercultures, so that a student who enrolls in a school in a new country brings with her a complex set of beliefs, perceptions, and behaviors related to privacy, cooperation/competition, personal space, eye contact, body movements, and physical contact. In addition, she possesses individual differences that are developed within a culture, which are often referred to as cognitive style. The features include such characteristics as analytic, methodical, reflective, global, relational, and intuitive (Reid, 1987; Scarcella, 1990). Helmer and Eddy (2012) also identify features such as assertiveness/ compliance, dominance/submission, and direct/indirect communication styles. Individuals also possess backgrounds that include information about family structure-roles of family members, child-rearing practices, gender roles, adult-child interactions, educational expectations, expression of emotions, conversational rules, child-rearing practices, individual responsibility, and spirituality. The difficulty, of course, lies in the fact that families exist within cultures, and their views and beliefs are formed through interactions with their broader culture, their family's first culture, and their local community's culture, to name a few.

Cultural influences are highly evident in classrooms. But this should not be a surprise, since schools everywhere are designed by persons who represent their cultures. There are variables that represent cultural features-sometimes directly, sometimes indirectly-that can help predict cultural inclusion and exclusion (Gunderson, 2009). Groups of variables can constitute factors.

Cultural differences can affect the degree to which an individual from one culture is included or excluded in the environment of another culture. There would appear to be hundreds of variables that could be identified that are either directly or indirectly related to culture. It would also appear doubtful that a useful model could account for them all. As a consequence, I will attempt to hypothesize factors that impact 
group dynamics in multicultural classrooms. It is important to note in advance that the proposed factors are neither mutually exclusive nor uniquely different in content.

\subsubsection{Country of origin}

The first factor to consider is a student's country of origin. Where do students come from? This often informs one about the kinds of schools a student has or has not attended. What are the reasons families leave their home countries? Most immigrant families that come to British Columbia (BC) report that their purpose is to get a better education for their children (Gunderson, 2007). Unfortunately, the country of origin often predicts an immigrant's likelihood of success in schools in BC because, in many cases, the country of origin is a marker of other underlying features that are associated with school success or difficulty. The country of origin is likely a factor that impacts school success around the world.

\subsubsection{Family}

The notion of what constitutes a family varies from country to country and, it would seem, within a country as well (Gunderson, 2007). This is one of the most powerful multicultural factors, and probably the most complex as well. Parents and their children have views of teaching and learning that are related to both the views of the first culture and the socioeconomic status.

We waste too much time in school. Too much time not working. Teachers are too lazy they don't tell you what to do. (Male, Cantonese, 15 years old)

The labs are better equipped in Canada, but the teachers don't show us what to do with them. (Female, Cantonese, 16 years old)

Many individuals from higher socioeconomic families generally view learning the way they view business (Gunderson, 2007). From this perspective, the teacher is responsible for supplying the pieces of knowledge, somewhat like products, that are needed to pass a test. The student's responsibility is to memorize (acquire) all of the knowledge the teachers deliver. A measure of success is the number of items the student gets correct in an examination. They have what Freire (1970) called the banking view of teaching. In some cases, the comments clearly differentiated those who were affluent ...

There aren't enough parking spaces at school (male, Mandarin, 18 years old).

Canada is really stupid because it builds big beautiful super highways but only lets you go $50 \mathrm{~K}$ an hour. That's a waste of money. They waste 
money on immigrants. They give tax money for immigrants to stay in Canada and all they are doing is taking advantage of Canada. It's not good use of tax. Canada people have to get smart, not waste money on people who don't work. (Female, Cantonese, 16 years old)

... from those who were less affluent:

ESL students work so hard. Even if you do really well you just get an ordinary job. They have no future, that's why so many drop out. Kids have to work to make enough money for comfortable life, no, not even comfortable life. In school there's gangs, there's drugs, oh, it's horrible thing and school's so small, it's unhealthy. I have a few cousins, they all drop out. There's no future so what's the point? You pay extra to go to better class. Money is so important. Most parents can't afford it. (Female, Vietnamese, 17 years old)

Variables related to the family factor are complex. What are the family dynamics? What is the family decision-making structure? Who should be contacted if needed at home? What is the naming system? How are individuals addressed? This is an important issue because the way an individual is addressed or named in some cultures may be considered impolite, insulting, or inappropriate in others. Are there communication patterns associated with different roles, such as those of a parent, child, teacher, or relative?

What are the general attitudes toward school and schooling? Are there strong overall cultural values that might make a difference? Are there views of teaching and learning that might impact students' and parents' views of the instruction occurring in a school? Are there epistemological differences in parental views about what should or should not be the focus of instruction? That is, do the teachers' views of what is valuable for students to learn the same as those of the parents? In some cases, teachers focus on process rather than product (Gunderson, 2000). Differences in views clash and the result is an unfortunate conflict between schools and homes (Li, 2006).

Often, religious orientation has a significant influence on how a family perceives what is being taught in school. What might this mean for teaching-learning relationships? What might this mean for teacherstudent, student-student, adult-student, and male-female relationships in school? There are numerous reports of clashes between the views or practices of teachers or the school and the religious views of parents. For instance, parents went to Federal Court in Tennessee (1986, Mozert v. Hawkins County Public Schools) because they felt their beliefs were being 
assaulted by the materials being used in their children's classrooms. DelFattore (1992) wrote this about the trial:

The protesters, who described themselves as born-again fundamentalist Christians, based their entire understanding of reality on their particular interpretation of the Bible. In their way of looking at life, all decisions should be based solely on the Word of God; using reason or imagination to solve problems is an act of rebellion. Everyone should live in traditional nuclear families structured on stereotyped gender roles. Wives should obey husbands and children their parents, without argument or question. (p. 36)

The reading books used by the teachers were filled with imaginary creatures, fantasy, and fairy tales. Parents were upset about the material, but they were as upset about the notion of asking learners to become critical readers. DelFattore (1992) further notes:

Imagination, like independent thinking and tolerance for diversity, has no place in the Hawkins County protesters' world view. They alleged that the process of imagination, regardless of the content, distracts people from the Word of God. Once the mind is open to imagination, all kinds of alien thoughts may enter, and the soul may be lost. Moreover, using imagination to solve problems substitutes a human faculty for the absolute reliance on God that is necessary for salvation. (p. 44)

In some cases students are not expected to ask questions of the teachers or of texts, while in other cases, they are. These differences in views are potentially extremely contentious.

\subsubsection{First and second languages}

Language differences can impact student interactions in school. What are some specific language features that might make a difference? Vietnamese speakers, for instance, find it difficult to learn English for various reasons (Honey, 1987). Honey notes, "Because their mother tongue has no inflections, differentiates words by tone, and makes great use of syntax and particles for grammatical purposes, Vietnamese find a language like English, which is so dissimilar to their own, very difficult to learn" (p. 238). There is a relationship between the degree to which one can communicate in the language of instruction and one's inclusion into the culture of the classroom. There is also an overall 
relationship between L1 and L2 that suggests individuals who speak an L1 that is similar to the L2 may find the latter easier to learn and, as a result, be included into the culture of the classroom. But again, compared to other factors, this relationship is not a major one. Language does make a difference, however.

The white kids are big and loud like gorillas. You have to get out of the way because they so big. They think they own school because they are born here. They are so, so loud you can't be a friends with them cuz they don't talk, they scream. They are so rude. (Male, Vietnamese, 15 years old)

Perceptions are influenced by L1 backgrounds in complex ways. Language can be a barrier to inclusion:

I spend two years with no friends, no one. I spend two years not talking, anyone. I go school, I go home, I talk only my mother, my brother. Best friend United States. Cry, all time, cry. Being sick, all time, sick, stomach hurt, head hurt, heart hurt, all time, bad dream, all time, all time. (Female, Kurdish, 16 years old)

\subsubsection{L1 teaching and learning practices}

The methods, procedures, and practices of teaching and learning in an individual's first culture or home country constitute a powerful factor in inclusion/exclusion. I conducted a number of factor analyses to explore English reading as a dependent variable and found that the standard models of L2 reading were not substantiated (Gunderson, 2007). It appears that instructional practice is a variable that may mask underlying differences. Students were taught in systems that used bottom-up teaching styles, and the results revealed bottom-up processing. Immigrants possess a deep-seated view of what constitutes teaching and learning. Many expect to be involved in activities that focus on rote memorization, attention to facts and details, teacher-centered instruction, and a focus on grades. Li (2006), for instance, found that the Chinese parents she studied rejected the teaching and learning going on in their children's school and opted, instead, to rely on activities outside school to give their children the skills they believed to be valuable.

\subsubsection{Overall numbers and inclusion/exclusion}

Schools and school districts in British Columbia vary greatly in the number of immigrant or ESL (English as a second language) students enrolled in them. The range extends from essentially zero immigrants to $100 \%$ 
(Gunderson, 2007). We designed a study to investigate whether ESL numbers make a difference in reading achievement. Two ESL consultants working in two large school districts were convinced that ESL numbers in a classroom likely affected the English reading achievement of students. They opined that there is probably a critical mass of ESL numbers that would have a negative effect on learning (Eddy, Carrigan, and Gunderson, 2008). We hypothesized that the smaller the ESL number was, the higher their learning would be because more models of the target language would be available to them. The findings were interesting and may say something about inclusion/exclusion.

The study took place in two large urban school districts and included six schools that enrolled students from kindergarten to grade seven. In total, there were 1,013 students in 33 classrooms involved. There were no statistically significant differences in mean income in the six schools. We measured the ratio of native English to ESL speakers; the results for the six schools were A: 87-13\%, B: 35-65\%, C: $64-36 \%$, D: $39-61 \%$, E: $23-77 \%$, and F: $68-32 \%$. Ratios varied dramatically from classroom to classroom (from 5\% to 90\% ESL). Reading achievement varied relative to the percentage of ESL students in the classroom. However, the relationship was not linear. Classrooms that had low and high percentages of ESL students scored lower than those that varied from $40 \%$ to $60 \%$. The relationship is similar to a bell curve. The results of the interviews suggest that inclusion was also associated with the number of ESL students.

Conversations with the teachers led the research team to conclude that ESL students in low ESL classrooms were, in essence, integrated into the classrooms based on the notion that they would learn English and how to read English simply because their classmates were English speakers and readers, not by making accommodations for their special needs and abilities. This feature is not one of inclusion, but of submersion. In short, these students were excluded unconsciously by being ignored. This finding was corroborated by three independent researchers, who observed and recorded notes over the nine months of the study.

Teachers in high ESL classrooms appeared overwhelmed by the challenges they perceived in the diversity of abilities their students represented. Students were excluded by having teachers ignore their special needs and abilities. Secondary-level students reported that they felt like they were excluded and that it was like being in a ghetto (Gunderson, 2007). Students felt ESL classes were for second-class students-those who had little chance to go on to university. ESL classes made students feel inferior, "like those who are crippled or blind." One 16-year-old 
male Polish student said, "People make fun of me because I was in ESL." As I argued, "Those who were in ESL classes the longest scored lowest on all of the examinable courses and also had the highest disappearance rate;" also, "parents complained bitterly that ESL classes were roadblocks to students' success and they interfered with the learning of examinable courses."

It was hard to make new friends. All my good friends are in Somalia. I don't know anyone in __ school who is from my country. (Male, Somali, 16 years old)

Too much Chinese. ESL class are fill with Chinese. Teachers no good, not stop Chinese talk. No help Spanish. I not passing nothing. (Male, Spanish, 14 years old)

I'm Kurd, Iraq. No one know (?), no one. Here, many India people, think we being India. Here Chinee people, think India. No one know I not India. (Male, Kurdish, 14 years old)

Too much Chinee talk. Too much Chinee people. No English. Bad class, teacher no good, not stop Chinese talk. (Male, Kurdish, 14 years old)

So, as a factor, I hypothesize that overall numbers and inclusion/exclusion are complex.

\subsubsection{Individual differences}

Human beings are unique in their ability to cope with elements of their environments. Different authorities and researchers have identified characteristics, such as analytic, methodical, reflective, global, relational, and intuitive, to describe individual differences in the way ESL learners make sense of and cope in the world, especially the classroom (for reviews, see Reid, 1987; Scarcella, 1990). It is unclear what individual differences account for as regards the finding that some students are able to achieve way beyond their apparent capacities in schools where the language of instruction is different from their home languages. These are the resilient students, and some believe resilience can be taught (Roesingh, 2004). Individual differences may account for students' inclusion or exclusion, but it is not clear how strong this factor is or whether teachers can, in fact, reliably and validly measure features associated with variables that make up this factor.

\subsubsection{The multicultural model}

The purpose of this model is to hypothesize variables that are associated with inclusion in multicultural classrooms where the cultural 
background of the student differs from the culture in the classroom. While there are hundreds or thousands of variables that likely influence the inclusion of a person from one culture into another culture, five factors are proposed here: family, first and second language, overall numbers, individual differences, and first cultural teaching practices. To explore these factors I have used an approach that features focus groups. Several members of a culture (usually no more than 10) are recruited to explore these factors. Practice has shown that the following focus questions are helpful in exploring the five factors (Gunderson, 2009). These questions can also form the basis of an inquiry into the culture of a particular school in order to describe first cultural features.

\subsubsection{Focus group questions}

(a) Where do students come from?

(b) What is the main religious orientation? (What might this mean for teaching-learning relationships? What might this mean for teacherstudent, student-student, adult-student, male-female relationships in school?)

(c) What are the reasons that families leave their home countries?

(d) What is the naming system? (How should people be addressed?)

(e) What are the family dynamics? (What is the family decision-making structure? Who should be contacted if needed at home?)

(f) Are there strong overall cultural values that might make a difference in "our" schools?

(g) What are general attitudes toward school and schooling?

(h) What specific language features might make a difference?

(i) Are there communication patterns associated with different roles, such as parent, child, teachers, authorities, and others?

(J) Are there ways in which the teacher can be sensitive to cultural differences?

\subsection{Focus group: An example}

Culture is difficult to define, as shown above. It is also difficult to get human beings to agree on what features are common in their own cultures. Gunderson (2009) notes,

The following observations were made at the University of British Columbia and were developed from a focus group. The reader is cautioned to consider the following as being an extremely limited view developed by five informants who themselves also made it 
clear that these views were very limited and non-representative. They also concluded and argued strongly that there is no single view that could adequately represent the broad category "Arab." It was noted by one member of the group that there was a great deal of contention and often bitter vituperation related to the inclusion of Egyptians as Arabs. It was noted that many Egyptians have deep respect for their rich cultural and historical roots and view Arabs as being nomadic wanderers without established cultural and historical roots. They often resent being included in the category. The reader is cautioned to remember that the results are dependent on the experience and backgrounds of a local group and they are related to where the individuals came from (Saudi Arabia and the United Arab Emirates).

The task is to compare the knowledge acquired about the first culture, as shown above, with the cultural features of the school to see the matches and mismatches, predict inclusion/exclusion, and identify areas in which the teacher might accommodate students from different cultures. A model is presented in Figure 4.1.

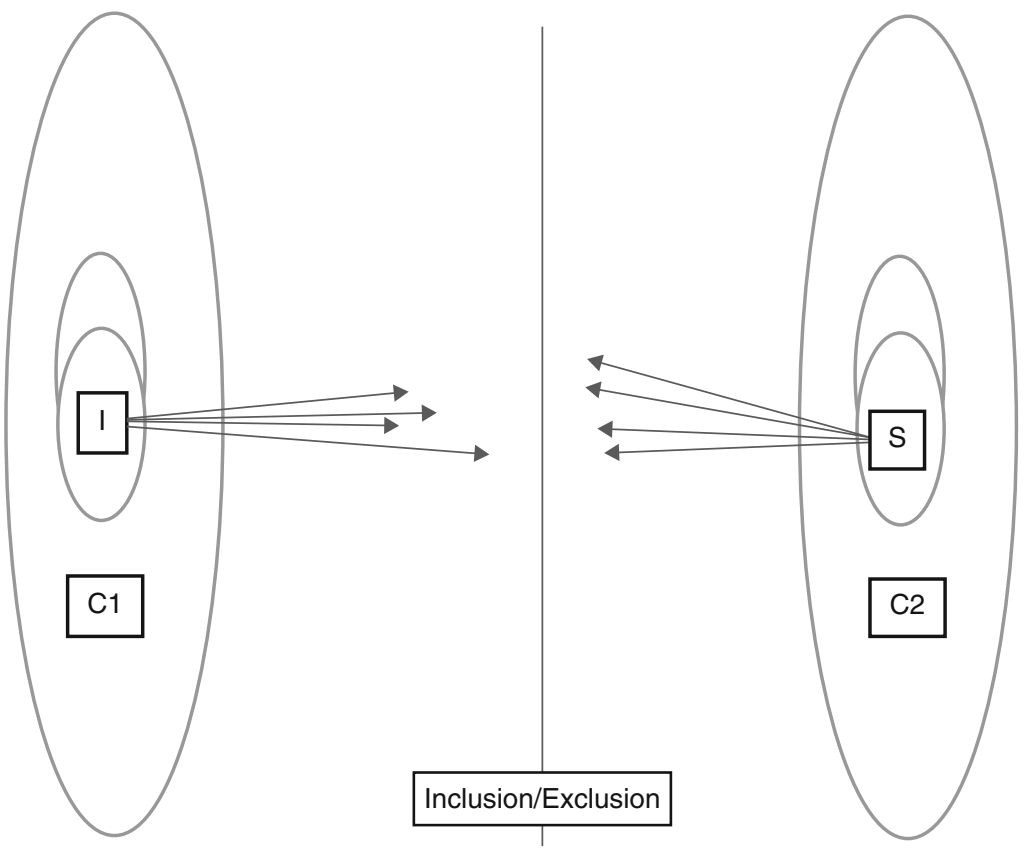

Figure 4.1 First (C1) and second (C2) cultures and inclusion/exclusion Source: Drawn by author. 
A student (I) possesses a complex cultural background that is a composite learned within the overall First Culture (C1). The background includes cultural features associated with family, community, and individual differences. The graphic contains only two intersecting local cultures, although in reality there are many. The second culture (C2) is just as complex. In this case, the school (S) and community cultures overlap within the larger national culture, although the graphic is also considerably less complex than it likely really is. The degree to which a student is included in the $\mathrm{C} 2$ is initially related to the match (or mismatch) of C1 and C2 features. The teacher's views are also reflected in the $\mathrm{C} 2$. In the case of Arabic speakers, the feature that may be problematic in some schools relates to gender roles. It may be difficult for a young Arabic-speaking immigrant boy to enter a classroom where the teacher is female. This would certainly have a negative effect on his inclusion into the culture of the classroom.

\subsection{Conclusion}

My purpose was to develop a model of inclusion/exclusion, where students' first cultural features differ from or match those of the classroom. Inclusion and exclusion are complex variables. One feature that is not mentioned has to do with national identities (Pickett \& Brewer, 2005). Individuals may not be included because of the way they are perceived relative to a national identity. Esses et al. (2005) conclude that "when national attachment takes the form of nationalism-belief in the superiority of one's nation over others-increased attachment is associated with unfavorable attitudes toward immigrants" (p. 332).

It was proposed that L2 focus groups should be organized within the local school community. Results should be considered local snapshots rather than grand generalizations. A focus group of local L1 individuals should also undertake the same exercise to develop a picture of the same school-related features.

Five factors were hypothesized to be important differentially in the degree to which they are associated with the inclusion of an individual of one culture into a school environment of another culture. As Duff and Talmy (2011) suggest, this approach is one that "addresses the manifold complexities of children or adults with already developed repertoires of linguistic, discursive, and cultural practices as they encounter new ones" (p. 97). As such, it can be described as an L2 socialization view.

Every country in Asia appears to have school-age immigrants enrolled in their schools. It appears that immigrant enrollment varies widely 
from country to country, area to area, and school to school. The potential for inclusion, theoretically, can be estimated by comparing the cultural features that immigrants bring to a school with the cultural features of the enrolling school (and teachers). Overall, absolute percentages of immigrant students in a classroom are hypothesized to roughly predict inclusion/exclusion, along with other factors. Thus, a small number of immigrants in a classroom will likely not be easily included, nor would students in a class that has a very high number of immigrant students.

At some point, it would be interesting to study the features of this model in classrooms that have varying numbers of immigrant students. At this point, the model is presented here to generate discussion, disagreement, and argument. As a test, one could compare the Arabic cultural features noted above with those in schools in Asia. The question to ask is how do these cultural features compare to the cultural features in my school in Japan, Korea, Taiwan, China, etc.? What potential difficulties might students have and what accommodations might a teacher make to include them?

\section{References}

Condon, J. C. Jr. (1973). When people talk with people. In C. David Mortensen (Ed.), Basic reading in communication theory (pp. 45-63). New York: Harper and Row.

DelFattore, J. (1992). What Johnny shouldn't read: Textbook censorship in America. New Haven, CT: Yale University Press.

Duff, P. A. (2010). Language socialization into academic discourse communities. Annual Review of Applied Linguistics, 30, 169-192.

Duff, P. A. \& Talmy, S. (2011). Language socialization approaches to second language acquisition: Social, cultural, and linguistic development in additional languages. In D. Atkinson (Ed.), Alternative approaches to second language acquisition (pp. 95-116). Oxford: Routledge.

Duff, P. A. \& Uchida, Y. (1997). The negotiation of teachers' sociocultural identities and practices in postsecondary EFL classes. TESOL Quarterly, 31, 451-486.

Ellis, R. (1985). Understanding second language acquisition. Oxford: Oxford University Press.

Ellis, R. (1994). The study of second language acquisition. Oxford: Oxford University Press.

Esses, V. M., Dovidio, J. F., Semenya, A. H., \& Jackson, L. M. (2005). Attitude toward immigrants and immigration: The role of national and international identity. In D. Abrams, M. A. Hogg, \& J. M. Marques (Eds), The social psychology of inclusion and exclusion (pp. 317-337). New York: Psychology Press.

Freire, P. (1970). Banking v. problem-solving models of education. Pedagogy of the oppressed (pp. 71-86). New York: Continuum. 
Gunderson, L. (2000). Voices of the teenage diasporas. Journal of Adolescent and Adult Literacy, 43, 692-706.

Gunderson, L. (2007). English-only instruction and immigrant students in secondary school: A critical examination. Mahwah, New Jorge: Lawrence Erlbaum Associates.

Gunderson, L. (2009). ESL (ELL) literacy instruction: A guidebook to theory and practice. New York: Routledge.

Gunderson, L., Murphy Odo, D., \& D'Silva, R. (2011). Second language literacy. In E. Hinkel (Ed.), Handbook of research in second language teaching and learning (Vol. II, pp. 472-487). New York: Routledge.

Helmer, S. \& Eddy, C. (2012). Look at me when I talk to you: EAL learners in non-EAL classrooms (3rd edn). Don Mills, Ontario: Pippin Publishing.

Honey, P. J. (1987). Vietnamese speakers. In M. Swan and B. Smith (Eds), Learner English: A teacher's guide to interference and other problems (pp. 238-251). Cambridge: Cambridge University Press.

Kroeber, A. L. \& Kluckhohn, C. (1954). Culture: A critical review of concepts and definitions. New York: Random House.

Larson, D. N. \& Smalley, W. A. (1972). Becoming bilingual: A guide to language learning. South Pasadena, California: William Carey Library.

Li, G. (2006). Culturally contested pedagogy: Battles of literacy and schooling between mainstream teachers and Asian immigrant parents. Albany: State University of New York Press.

Murdock, G. P. (1961). The common denominator of cultures. In R. Linton (Ed.), The science of man in the world crisis (pp. 123-142). New York: Columbia University Press.

Pickett, C. L. \& Brewer, M. B. (2005). The role of exclusion in maintaining ingroup inclusion. In D. Abrams, M. A. Hogg, \& J. M. Marques (Eds), The Social psychology of inclusion and exclusion (pp. 89-111). New York: Psychology Press.

Reid, J. M. (1987). The learning style preferences of ESL students. TESOL Quarterly, 21(1), 88-112.

Richard-Amato, P. A. (1988). Making it happen: Interaction in the second language classroom: From theory to practice. New York: Longman.

Roesingh, H. (2004). Effective high school ESL programs: A synthesis and metaanalysis. Canadian Modern Language Review, 60, 611-636.

Scarcella, R. C. (1990). Teaching language minority students in the multicultural classroom. Englewood Cliffs, New Jersey: Prentice-Hall Inc.

Schieffelin, B. B. \& Ochs, E. (1986a). Language socialization. Annual Review of Anthropology, 15, 163-191.

Schieffelin, B. B., \& Ochs, E. (Eds) (1986b). Language socialization across cultures. New York: Cambridge University Press.

Schumann, J. (1978a). The acculturation model for second-language acquisition. In R. C. Gingras (Ed.), Second language acquisition and foreign language teaching (pp. 27-50). Washington, DC: Center for Applied Linguistics.

Schumann, J. (1978b). Psychological factors in second language acquisition. In J. C. Richards (Ed.), Understanding second language and foreign language learning (pp. 163-178). Rowley, Massachusetts: Newbury House Publishers.

Schumann, J. (1986). Research on the acculturalization for second language acquisition. Journal of Multilingual and Multicultural Development, 7, 379-392.

Talmy, S. (2012). Second language socialization. In P. Robinson (Ed.), Routledge encyclopedia of second language acquisition (pp. 571-575). New York: Routledge. 
Vontress, C. E. (1976). Counseling the racial and ethnic minorities. In G. S. Belkin (Ed.), Counseling: Directions in theory and practice (pp. 277-290). Dubuque, Iowa: Kendall/Hunt Publishing Company.

(c) (i) Except where otherwise noted, this work is licensed under a a copy of this license, visit http://creativecommons.org/licenses/by/3.0/ 